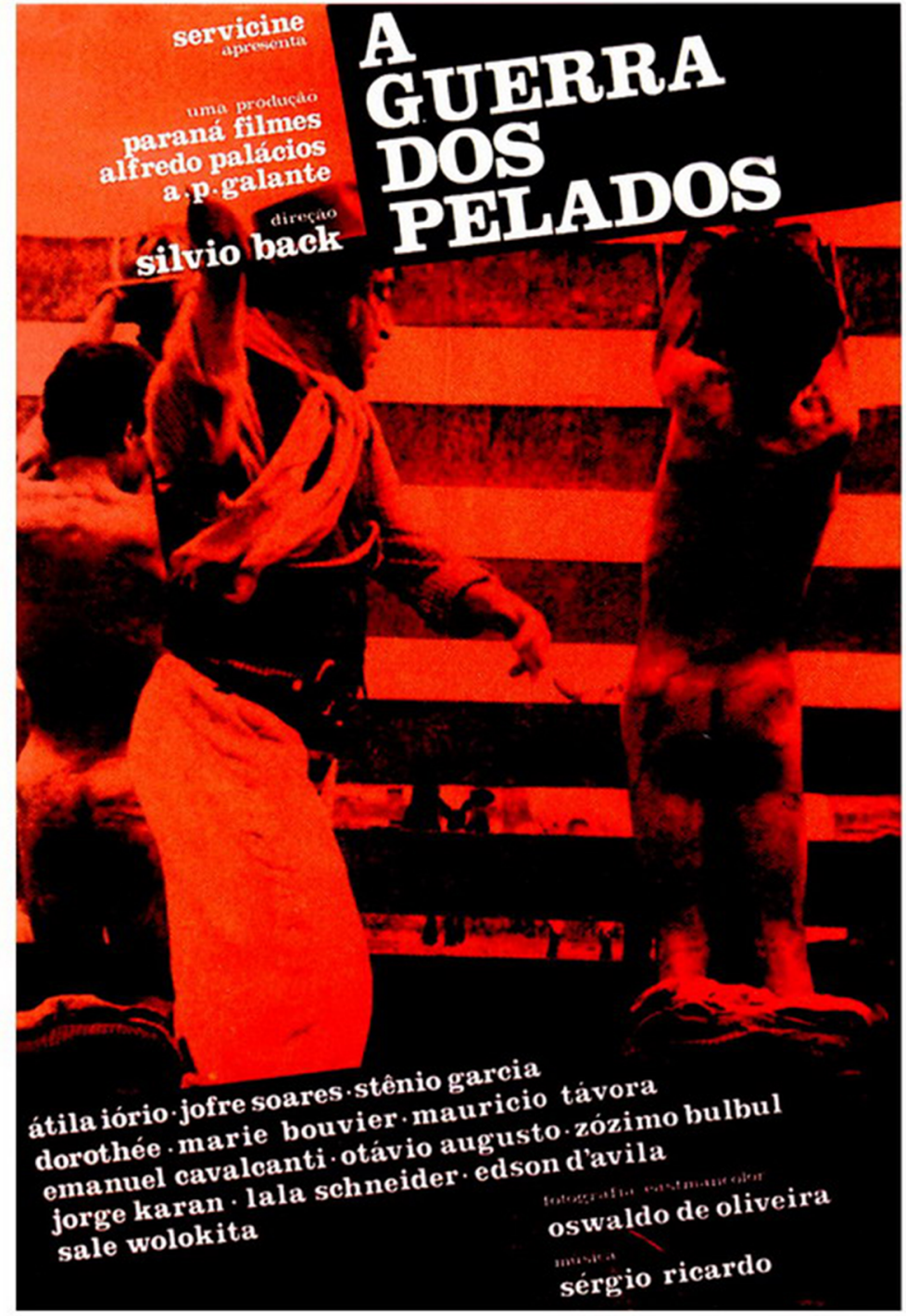

Cartaz do filme A Guerra dos Pelados de Silvio Back, 1971: Disponível em: < http://www. cinemabrasileiro.net/cartazes/A\%20guerra\%20dos\%20pelados-cartaz1.jpg > 


\title{
Imagem e alegoria no cinema de Sylvio Back: o caso de Ana
}

\author{
Image and allegory in Sylvio Back's cinema: Ana's case
}

\author{
Rosane Kaminski ${ }^{1}$
}

\begin{abstract}
ResUmo:
Este texto discute sentidos alegóricos da imagem cinematográfica. O objeto de análise é o filme A Guerra dos Pelados (Sylvio Back, 1971). É um filme histórico sobre o Movimento do Contestado. $\mathrm{O}$ assunto é a resistência dos camponeses. Estes foram expulsos de suas terras e resistem à opressão dos fazendeiros e industriais da região. Na narrativa do filme, analisa-se o significado emblemático da personagem Ana, uma jovem camponesa. A imagem de Ana é uma possível chave de leitura para o filme. As diferentes fases da trama se relacionam com as fases vividas por ela. A escolha do cineasta em demarcar fases do filme a partir das transformações na imagem de uma mulher é uma opção retórica. Ele usa a imagem como alegoria que expressa múltiplos sentidos.
\end{abstract}

Palavras-chave: Imagem cinematográfica. Sylvio Back. Alegoria.

\section{ABSTRACT:}

This paper discusses allegorical meanings of cinematic image. The object of analysis is the movie A Guerra dos Pelados (Sylvio Back, 1971). It is a historical film about the Contestado War. Its subject is the peasants' resistance. They were expelled from their land and resist the oppression of farmers and industrial owners in the region. In the movie's narrative, we analyze the symbolic meaning of the character Ana, a young peasant woman. The image of Ana is a possible key for interpreting the movie. The different stages of the plot are related to the stages in her life. The director's choice to demarcate the movie stages from transformations in a woman's image is a rhetorical option. He uses this image as an allegory that expresses multiple meanings.

Key-words: Cinematographic image. Sylvio Back. Allegory.

1 Professora Adjunta da UFPR, atua na graduação e no Programa de Pós-Graduação em História. Doutora em História pela Universidade Federal do Paraná e mestre em Tecnologia pela Universidade Tecnológica Federal do Paraná, é líder do grupo de pesquisa NAVIS - Núcleo de Artes Visuais. e-mail: rosanekaminski@gmail.com 


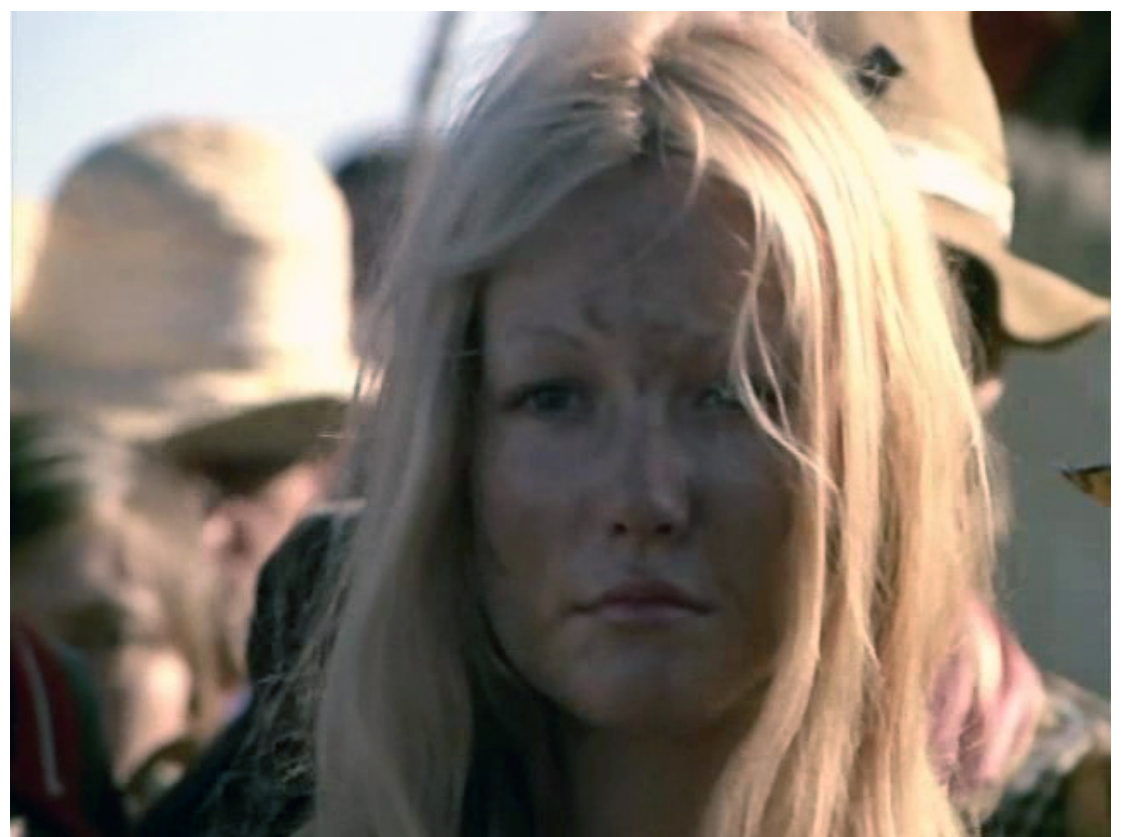

Figura 1: A personagem Ana (Dorothée-Marie Bouvier), no filme A Guerra dos Pelados (Sylvio Back, 1971).

\section{Introdução: imagens e alegorias}

O objeto de análise neste texto é o filme histórico A Guerra dos Pelados (Sylvio Back, 1971). Este será avaliado não como uma narrativa explicativa do passado, mas como um produto audiovisual por meio do qual o cineasta problematiza questões candentes do seu tempo de produção'.

O eixo da análise aqui proposta se pauta na transformação que a imagem da personagem Ana (representada por Dorothée-Marie Bouvier), uma jovem camponesa, vivencia no filme. Ana é uma personagem simbólica na obra, pois as diferentes fases da trama se relacionam diametralmente com as fases vividas por ela. A escolha do cineasta em demarcar fases do filme a partir da transformação na imagem de uma mulher é vista, neste texto, como uma opção retórica, ou seja, a utilização da figura feminina enquanto alegoria de uma mudança que perpassa o filme como um todo.

A intenção do artigo é explorar a relação entre as mudanças em Ana e os sentidos do filme, bem como analisar alguns dos recursos expressivos utilizados para representar visualmente essas mudanças, articulando-os a outras referências pictóricas e culturais. A partir dessa análise, pretende-se refletir sobre os possíveis significados evocados por essa opção retórica do cineasta frente ao contexto de produção do filme, durante os anos mais duros da ditadura militar no Brasil.

Uma vez que o objeto deste estudo constitui-se de um conjunto de imagens cinematográficas, cabe esclarecer, desde já, qual o entendimento pretendido para um termo abrangente quanto "imagem". Partindo das definições dos semioticistas Santaella e Nöth (1998: 36), pontuo a existência de duas dimensões imbricadas nesse conceito: a imagem direta perceptível (ou seja, uma representação material); e a imagem mental simples, que pode ser evocada na ausência 
de estímulos visuais (imaginação). Ou seja, quando falo de imagem cinematográfica, esse conceito articula os âmbitos tecnológicos (meios, dispositivos e recursos expressivos) que conferem existência a uma imagem direta perceptível, aos âmbitos semânticos da experiência perceptiva visual, carregados de memórias e significados históricos. A imagem, nesse sentido, é antes de tudo um fenômeno que se processa pela relação entre o sujeito que percebe e a imagem direta perceptível, ou o "arranjo visual" que desperta significados culturais. Tal forma de entender o conceito de imagem também se apoia em Hans Belting (2005: 65), quando ele pergunta: "O que, então, é uma imagem? Ou: onde está a imagem? Está em nosso olhar ou apenas em sua memória, e até que grau ela está no impresso?". Para clarear suas reflexões acerca desse duplo caráter da imagem (material e mnemônico), Belting lembra da distinção inglesa entre image [imagem] e picture [gravura], o que ajuda a compreender a "busca da imagem no retrato" (BELTING, 2005: 66). Isso posto, é bom deixar claro, desde já, que a análise isolada de cada imagem direta perceptível, em suas configurações técnicas ou materiais, não é o propósito nesse texto.

A abordagem que pretendo seguir na análise das imagens de Ana no filme de Sylvio Back, parte do entendimento de que as imagens evocam múltiplos sentidos ao serem analisadas diante de seu contexto cultural e histórico de produção, o que implica levar em conta seus valores semânticos, estéticos e políticos. Ao considerar o caráter polissêmico e ambíguo das imagens aqui selecionadas, caracterizadas pela superposição e convergência de significados, percebe-se nelas uma potência alegórica. Portanto, tais imagens - constitutivas de uma narrativa ficcional de conteúdo histórico - serão tratadas enquanto alegorias.

O sentido etimológico do termo grego allegoria, composto de allos (outro) + agoreuein (falar em público, dizer), significa "dizer de outro modo", falar alguma coisa referindo-se a outra (GRAWUNDER, 1996: 19). Ismail Xavier (2012: 465-466) lembra que, ainda que distante das discussões contemporâneas sobre alegoria, esse sentido original da palavra já carrega o reconhecimento de que a linguagem não é "imediata", de que há mediação reconhecida de uma convenção interposta entre a fala e a experiência. Tal caráter substitutivo, de estar em lugar de alguma outra coisa com função representativa, é essencial em todas as imagens figurativas, independente do suporte. É isso que as caracteriza enquanto signos. No que diz respeito às imagens cinematográficas, seja em filmes com narrativas teleológicas e montagens "transparentes" ${ }^{2 "}$ , seja em filmes de vanguarda em que o descontínuo e a fragmentação vêm à primeiro plano, o caráter de mediação está presente. No primeiro caso, prevalece a dimensão sígnica de representação que é típico de todas as imagens figurativas. No segundo caso, torna-se evidente o caráter de apresentação de si mesmo enquanto signo (o chamar a atenção para a própria forma como assunto da obra, característico das artes de vanguarda).

Tanto num caso quanto em outro, podese buscar em diferentes tipos de filme algum sentido alegórico, considerando que são produtos ficcionais e/ou artísticos. Como diz Grawunder no início do seu livro sobre a alegoria, "toda realização no terreno da Arte, como lugar de aparência de significados, em sua própria essência contém o elemento de alteridade e constitui-se em sentidos possíveis, oferecendo- 
se à suposição de ser sempre uma alegoria" (GRAWUNDER, 1996: 19). Noutro momento, ela cita Angus Fletcher para dizer que "deve-se estar disposto a discernir, em quase toda obra de ficção, um mínimo de alegoria", sendo que numa narrativa "mudanças súbitas de atmosfera funcionam como sinais alegóricos" (ibidem: 164). Essa afirmação condiz com os propósitos de análise neste texto.

Ismail Xavier, que estudou um período do cinema brasileiro marcado pelo recurso à alegoria ${ }^{3}$, diz que as análises em torno da estratégia alegórica nos filmes são geralmente abordadas em dois aspectos: o da descrição da textura e estrutura da obra e o da discussão da postura do artista diante da sociedade (XAVIER, 2012: 445). Todavia, ele mesmo alerta para que não se reduza o recurso da alegoria "a um programa imediato de denúncia programada e velada do regime autoritário". Mais do que isso, tal recorrência implica em "uma gama de motivações e estratégias de linguagem, bem como de efeitos de sentido conforme a postura estética do cineasta, sua forma de organizar o espaço e o tempo, e sua relação específica com o espectador" (Ibidem: 31).

Buscaremos, nesse texto, avaliar as figurações da personagem Ana sob esse duplo aspecto. As transformações vividas por essa personagem no filme $A$ Guerra dos Pelados serão pensadas, portanto, enquanto sinais alegóricos capazes de acionar sentidos estéticos, políticos e históricos. Tais sentidos serão abordados a partir de um olhar sobre a estrutura da obra, considerando suas dimensões de temporalidade narrativa e diegética, e também a partir da postura do cineasta frente ao momento de sua produção.

Como o A Guerra dos Pelados é um filme histórico, a questão da organização do tempo será apresentada, a seguir, considerando três diferentes dimensões: o contexto temporal em que o filme foi produzido, a temporalidade do assunto representado, e a forma de organizar o tempo no âmbito narrativo, da montagem cinematográfica.

Temporalidades do filme: contexto de produção, contexto diegético e momentos da narrativa

A Guerra dos Pelados foi filmado em 1970, no interior de Santa Catarina, Brasil, quando Emílio Garrastazu Médici ocupava a presidência do país, ou seja, o período mais violento da ditadura militar. Em dezembro de 1968 o governo federal havia decretado o Ato Institucional $n^{\circ} 5$ e fechado o Congresso Nacional, enrijecendo o regime militar em vigor no Brasil desde 1964 e intensificando o uso de práticas repressivas.

O governo Médici, como é sabido, ficou marcado por duas faces distintas: enquanto que no âmbito econômico o país caminhava para o momento do dito milagre econômico brasileiro (impulsionado grandemente pelo crescimento do investimento de capital estrangeiro), no âmbito político a repressão se intensificava, justificando o rótulo dos anos de chumbo: a censura recrudesceu e as prisões e torturas se tornaram uma constante. Uma espécie de sombra pairava sobre os intelectuais e artistas mais engajados do país. Mas a esse quadro político caracterizado por violentos mecanismos institucionais, combinava-se o crescimento dos meios de comunicação e a necessidade de expansão do mercado e produção cinematográficos. E desde 1969, a partir do surgimento da Embrafilme, "a atividade cinematográfica teve assegurada a sua mais eficiente expressão dentro do aparato do Estado" (AMÂNCIO, 
2000: 123).

Já em fins dos anos 1960 o governo federal passou a estimular a produção de filmes históricos. A revista Filme Cultura, pertencente à Embrafilme, publicava em 1970 alguns dos temas sugeridos pelo então Ministro da Educação Jarbas Passarinho: F.E.B, Santos Dumont, Oswaldo Cruz, entre outros. As adaptações de obras literárias brasileiras também eram estimuladas. Aliás, a primeira obra lançada pela Embrafilme foi São Bernardo (Leon Hirszman, em 1972), que consistia justamente numa adaptação do romance homônimo de Graciliano Ramos, publicado em 1934.

Mas isto não significa que todos os filmes históricos ou adaptados da literatura tenham resultado de esforços governamentais, ou que tenham sido afinados com a ideologia do governo em vigor quando de suas produções ${ }^{4}$. No início dos anos setenta, tanto A Guerra dos Pelados quanto São Bernardo, ou ainda o filme Os Inconfidentes (Joaquim Pedro de Andrade, 1972) são exemplos de obras em que os cineastas se utilizaram da narrativa histórica para questionarem a própria História.

Como dito na introdução deste texto, tal contexto cinematográfico brasileiro também incluía a recorrência à alegoria enquanto um recurso expressivo articulado à consciência da crise do país. Dentre esse tipo de produção cinematográfica, situo A Guerra dos Pelados. Trata-se do segundo longa-metragem feito por Sylvio Back que, por meio de filmes, participava dos debates políticos e culturais daquele tempo. Para essa produção, ele não contou com verbas da Embrafilme, mas o filme chegou a receber o Prêmio de Qualidade concedido pelo Instituto Nacional de Cinema em 1971. Isso pode ser considerado, de certa forma, um benefício que o cineasta obteve diante daquela política cultural. Mas não deixa de ser um paradoxo: o mesmo filme que abordava criticamente temas urgentes - como a guerrilha camponesa e a repressão - era premiado por um órgão que pertencia ao Estado repressor.

Segundo palavras do próprio Back: "Pelados é um filme utópico, espelho da época e das coisas em que eu acreditava" 5 . Ele não apenas narrou um momento da história brasileira através do cinema, mas construiu esta narrativa a partir do modo como percebia o momento histórico em que ele mesmo vivia.

No âmbito diegético, o filme de Back tem como assunto o Movimento do Contestado, um conflito armado pela posse da terra que ocorreu no Sul do Brasil entre 1912 e $1916^{6}$. A ênfase recai sobre uma coletividade de agricultores, os "Pelados" (assim chamados por que raspavam o cabelo), que tentavam resistir à desapropriação das terras que habitavam e cultivavam. Isso decorria da exploração madeireira na região, articulada à construção da estrada de ferro ligando São Paulo ao Rio Grande do Sul. Apesar da resistência dos camponeses locais frente às constantes desapropriações, eles foram dizimados por jagunços (apelidados de "Peludos") que trabalhavam para os fazendeiros da região e pelas forças militares.

Mesmo tendo como tema um evento histórico e participando da construção de uma memória sobre esse evento, A Guerra dos Pelados é um filme ficcional, no qual os personagens são esquemas elaborados a partir da síntese de certas características que se quer discutir. Como se sabe, nas alegorias "os personagens não são apenas elementos de um conto ou romance, mas concretizações de ideias abstratas, símbolos específicos, nucleares no universo contextual, na lógica interna do discurso" (GRAWUNDER, 1996:163), por meio das quais se observa a 
comunicação e diálogo do autor com seu tempo.

Nesse sentido, quando Back filmou $A$ guerra dos pelados, trouxe para as telas representações de eventos efetivos do passado brasileiro, como a luta pela terra e a guerrilha no campo. Mas ele falava também sobre questões do seu tempo presente, como as esquerdas brasileiras se armando para lutar contra a ditadura militar e a imposição da modernização capitalista. O filme é carregado de ambiguidade: por um lado, tem como assunto a resistência; por outro, sua estrutura narrativa está impregnada pela incredulidade do autor frente às possibilidades efetivas de transformação social. Para entender como isso se processa, uma possível chave de leitura é a função alegórica da personagem Ana no enredo e na estrutura do filme, assunto a ser tratado no próximo tópico.

Quanto à organização temporal da narrativa fílmica, A Guerra dos Pelados compõe-se de três partes: um prólogo seguido de dois blocos, que apresentam ritmos distintos e correspondem a duas diferentes fases na trajetória dos Pelados.

O prólogo, num estilo sintético de representação, situa rapidamente o espectador no conflito central que move o filme: a disputa pela posse da terra. Apresentase antes dos letreiros de apresentação do filme. Na sequência inicial, ouve-se uma voz radiofônica avisando que as faixas de terras às margens do Rio do Peixe pertencem à Estrada de Ferro São Paulo-Rio Grande. Ao mesmo tempo, vê-se uma sucessão de planos focando uma cerca de arame farpado, e em seguida um grupo de jagunços ameaça moradores locais, avisando que se retirem das terras. Alguns resistem. A cena seguinte mostra os corpos de tais moradores dependurados em uma árvore. Os letreiros - durante os quais é enfatizado o teor comunitário dos camponeses, mostrados em atividades festivas e rituais como chimarrão, churrasco, rodas musicais, danças - fazem a separação entre este prólogo e os dois blocos do filme.

Em seguida, assiste-se à primeira fase vivida pelos Pelados no seu confronto com os Peludos. As motivações para o confronto bélico são expostas aos poucos nas sequências de cenas alternadas entre o grupo dos Pelados e os donos de madeireiras e fazendeiros da região. Nessa primeira fase do filme, a comunidade de camponeses parece forte, coesa, e sua resistência ao poder opressor sustenta-se pela fé religiosa do grupo, que crê nas profecias do falecido monge José Maria e na santidade de Ana, jovem que incorpora o monge durante os rituais religiosos. Também nessa fase ocorre a chegada dos militares enviados pelo governo ao local para resolver o conflito.

A ruptura que marca a passagem de um bloco a outro ocorre quando Ana abdica da condição de santa, preferindo entregar-se ao amor por um homem. A partir daí observa-se o declínio nas forças e na união dos Pelados, até seu quase extermínio.

A "não-santidade" de Ana se torna pública durante uma procissão religiosa. Depois disso, a coesão dos camponeses tende a declinar, o ritmo do filme torna-se cada vez mais lento, apresentando demoradamente a série de batalhas em que eles são massacrados pelos Peludos e pelos soldados do governo que intervém na luta. Não há um remate, e o filme simplesmente termina quando os poucos sobreviventes se retiram em direção ao município vizinho. Aliás, pela inexistência de um "fim", resulta uma incômoda sensação de incompletude.

Chama a atenção a função alegórica de Ana, única figura feminina relevante no filme. De início, ela é uma jovem virgem 
considerada santa pela comunidade messiânica. Mas a partir da sua tomada de posição, ao assumir-se como mulher, Ana adquire nova função dentro do grupo: empunha uma arma, monta um cavalo e passa a figurar entre os guerrilheiros que lutam contra o poder opressor.

Vejamos a articulação de cada momento de Ana com as duas fases que compõe a narrativa.

\section{Ana como emblema da fé: força aglutinadora}

Logo no início do primeiro bloco, descobre-se a motivação religiosa que unifica o grupo dos Pelados e a existência de uma santa entre eles. Ainda antes de vermos a imagem de Ana, sabe-se dela pela fala de outros personagens. Através de alguns diálogos, percebe-se a existência de pequenas divergências nas opiniões internas ao grupo, 0 que lhe confere certa heterogeneidade, mas não o suficiente para suplantar a ideia de coletivo. Isso ocorre, por exemplo, no planosequência que mostra quatro personagens à saída da igreja.

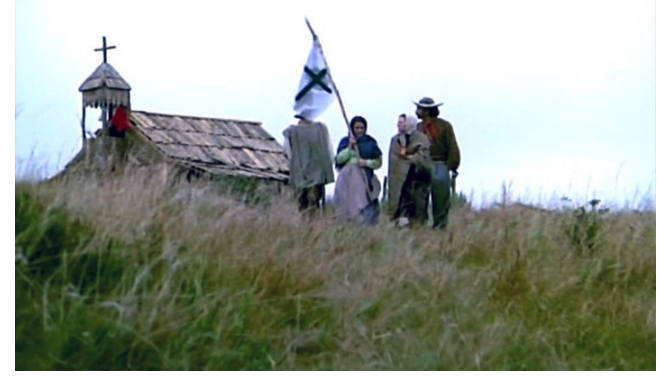

Figura 2: A saída dos fieis. A Guerra dos Pelados (Sylvio Back, 1971).

A câmera está um pouco afastada do grupo, a princípio fixa. Ao fundo, no alto, vêse parte da pequena igreja, e ouve-se o som de um sino. Dois homens e duas mulheres se afastam da igreja, andando em direção à câmera, que agora se move para trás. Uma das mulheres carrega uma bandeira branca com uma cruz. Um dos homens diz:

Boca Rica - Prá mim essa guria tá de velhacada! De inspiração ela não tem é nada.

Mulher com bandeira - Ana tem poderes! Seu Juca diz que ela vê o monge...

Zeferina - O meu Nenê ficou avariado por ela. Mulher com bandeira - Pecado! (faz o sinal da cruz).

Boca Rica - Mulhé acreditam em tudo. Eu tenho é dó do Nenê...

Homem - Eu não digo que credito nem que desacredito. Vâmo esperá.

Mulher com bandeira - Nós não merecemo essa graça de falá co santo José Maria. Só os puro. Homem - Graças a ela os Pelado tão tudo aqui. E os Peludo, nem fantasma deles!

Mulher com bandeira - Sabe de uma coisa, ela tá se purgando ainda. Não Custa!

Boca Rica - Purgando? Não vê que é empulhação da grossa?

(As mulheres se afastam, com gestos de indignação).

Boca Rica (dirigindo-se ao outro homem) - Pra mim, esta Ana ta percisando é de um ó... (faz gesto com as mãos, sugerindo o tamanho de um pênis).

Homem - Seu Boca, o senhor, heim?

Nesta cena se percebe que a relação entre fé e resistência coletiva é matizada por um mau agouro já no início do filme, pelos comentários maliciosos de Boca Rica sobre a falsa pureza da moça.

A fala dos Pelados, ao longo de todo o filme, é bastante sintética, indicando uma estrutura de pensamento simples e esquemática. As frases dos quatro personagens não precisam ser longas e explicativas. São suficientes, entretanto, para apontar a diferença de matizes que há dentro daquele grupo em torno de um elemento aglutinador da coletividade: a fé religiosa, mais forte e ingênua em uns, menos em outros. A escolha dos poucos signos que ambientam a cena se torna, assim, decisiva sobre os efeitos de 
sentido. A presença da igreja, do som do sino, e da bandeira na cena acima descrita fazem o papel de ambientação do diálogo e ajudam a situar o espectador dentro do tempo-espaço representado: a saída do ritual religioso e o provável testemunho de algum transe místico da santa.

Pouco depois, é afirmada a condição mística de Ana quando ela aparece em cena pela primeira vez, em transe mediúnico num ritual religioso. Seu rosto, em close, está iluminado e destaca-se contra um fundo escuro. Os olhos fechados, a cabeça girando e o cabelo dourado criam um clima barroco e sugerem o transe. Ao lado de Ana está Pai Velho, líder religioso do grupo. Estão no interior da igreja. Ao fundo, uma estátua de São Sebastião. Na parede rústica, um retrato do monge São José Maria. Ana veste um manto branco e é banhada pelo sol que entra em diagonal. Ela começa a proferir algumas palavras enigmáticas, a princípio desconexas, e depois assume a fala do falecido monge. O Pai Velho grita: Viva São José Maria!... e os outros reforçam: Viva!!

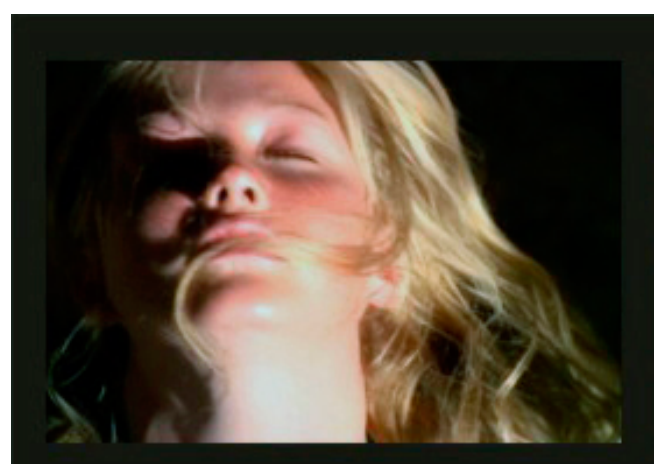

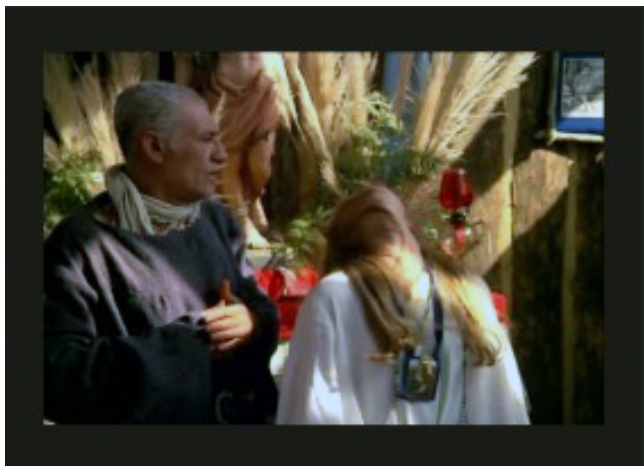

Figura 3: Transe místico de Ana (Dorothée-Marie Bouvier), ao lado do Pai Velho (Jofre Soares). A Guerra dos Pelados (Sylvio Back, 1971).

Estão presentes Adeodato (líder militar do grupo) e Boca Rica, entre outros Pelados. Um jovem de nome Ricarte agita o incensório. Todos voltam os olhos para Ana que, em êxtase, grita profecias ameaçadoras aos inimigos dos crentes. Após uma espécie de clímax, a moça cai exausta. Ricarte atende-a prontamente, cuidadoso.

Noutra sequência, Ana viaja a cavalo até um município vizinho e Ricarte a escolta. Num descanso em meio à viagem vemos Ana nos braços do seu protetor, revelando o romance entre os dois. No trecho que se passa imediatamente após essa revelação, atestamos a "falha" do poder mediúnico da jovem.

Novamente, trata-se de um ritual religioso e coletivo. Num plano geral, vê-se dezenas de pessoas caminhando numa formação circular. Ouve-se uma ladainha entoada pelo grupo e o ritmo é marcado por uma percussão. A câmera flagra o rosto de Ricarte, que recita a ladainha mas olha para Ana. Ela, de costas, logo se vira para encontrar o olhar do amante por alguns instantes. O espectador é testemunha do romance secreto dos dois.

Em seguida, a câmera nos mostra, por um breve instante, uma dúzia de soldados do governo atravessando um riacho, e logo 
outro plano nos restitui a vista dos Pelados, enquadrando a procissão de perfil. Com esse enquadramento pode-se ver que Pai Velho está à frente do grupo. Ele carrega nos ombros a estátua de São Sebastião, e tem Ana ao seu lado. Logo atrás deles vem o Adeodato. A ladainha continua:

...Ó virgem Santíssima me hai de valer, Me hai de valer na maior aflição. Meu Deus vos entrego alma e meu coração..
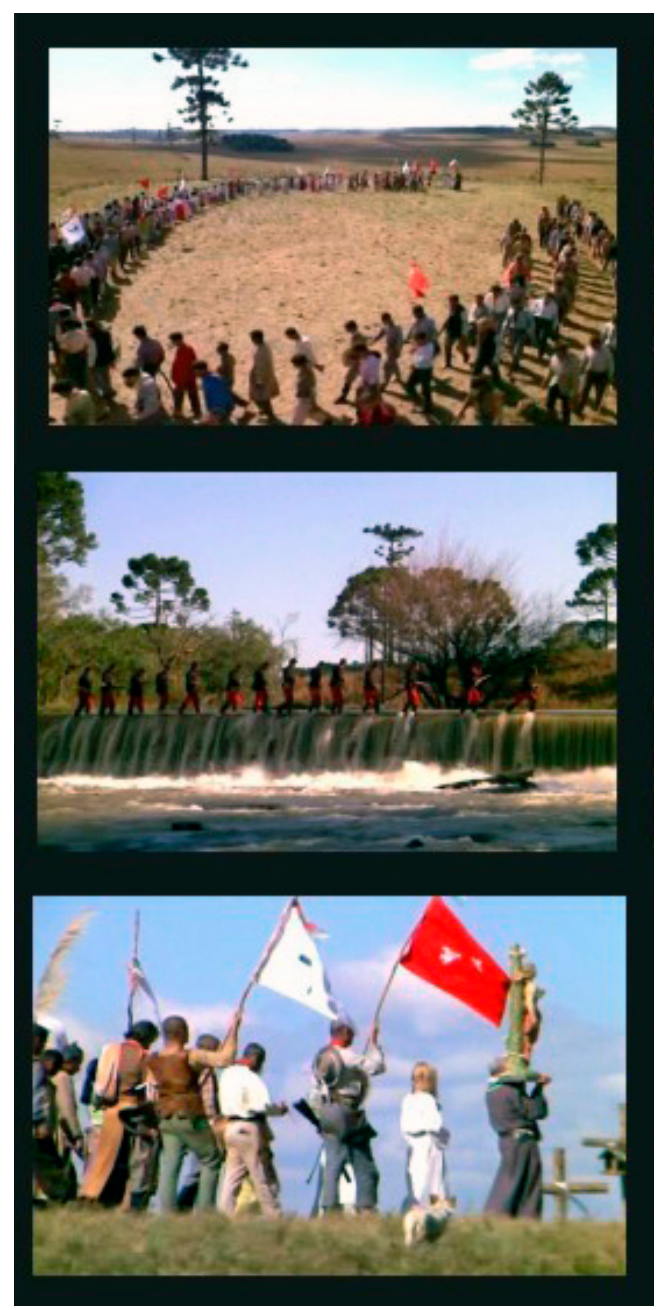

FIGURA 4: A procissão dos fiéis e os soldados preparando 0 ataque. A Guerra dos Pelados (Sylvio Back, 1971).

A alternância de planos que se segue, em que se vê ora a procissão dos Pelados, ora os soldados do governo empurrando canhões entre a mata, sugere que os últimos preparam um ataque à comunidade de crentes exatamente ao mesmo tempo em que ocorre o ritual.

A voz de Pai Velho se sobrepõem ao coro do grupo, puxando a ladainha. Ele observa Ana, que olha para trás outra vez, e chama a sua atenção, severo:

Pai Velho - Se aconcentre, Ana! Se aconcentre! Ana - Eu não consigo...

Pai Velho - Assim não dá!... Assim não dá!! (Pai Velho deposita a estátua no chão, e encosta uma ponta da sua veste sobre a testa da moça, que se encontra de olhos fechados, enquanto ambos são observados pelo resto do grupo) Se aconcentre! você até parece que tá sonhando...

Boca Rica, um pouco mais atrás, diz: "Tá vendo no que deu a santidade dela?". A câmera, agora, gira em torno da cena, oferecendo vistas da situação em diferentes ângulos. Pai Velho levanta os braços e grita: "Isso até parece um aviso do santo monge!". Adeodato concorda com Pai Velho: "é... deve sê algum castigo do céu que vem por aí..."

No quadro descrito, Pai Velho aparece como autoridade que exige de Ana um comportamento adequado perante o grupo. Boca Rica faz, ironicamente, a vez de comprovação das suspeitas que tinha sobre a falsidade da santa. Nenhum crente agora ousa defender Ana, ou afirmar sua evidente santidade, pois não houve eficácia no ritual. Ana e Ricarte permanecem mudos: ambos sabem a que se dá a sua falta de concentração. Adeodato, como líder, sugere que há "mau espírito" entre eles, gente que "não acredita". Põe a culpa da ineficácia na falta de confiança dos fiéis, o que compromete a coesão do grupo. Quando retomam a procissão e a ladainha, os soldados que vinham armando o ataque surpresa investem com armas de fogo. 
A conexão entre o enfraquecimento da fé e a investida do exército é explícita. A fraqueza de Ana surge como emblema desse momento de fragilidade do grupo de camponeses.

Ana, cuja entrega ao amormundano impossibilitou o ato mediúnico, sofre pela consciência de sua escolha. Em pensamento, suplica ao monge perdão pelo seu ato, como indica a voz over na cena em que Ana agita a bandeira branca diante dos soldados que acionam o canhão: Perdão, meu são José Maria! Perdão! Eu não fiz por mal de nascença...

Toda esta sequência possui extrema importância dentro do enredo do filme, pois nela são postos em ação inúmeros detalhes significativos para a construção de sentidos: a associação entre a fé e a "força dos Pelados"; a personagem Ana como alegoria dessa fé, pautada na ingenuidade e no misticismo; e a analogia que Sylvio Back cria entre a "perda da santidade" de Ana e o começo do declínio do grupo. Na teleologia fílmica, esta é a linha que demarca duas fases distintas do enredo, ainda que contínuas. $O$ destino do grupo prende-se, então, ao destino escolhido por Ana. Em âmbito mais amplo, extra-fílmico, essa construção do filme em duas fases (sendo a segunda marcada pelo declínio e derrota do elemento central do filme, que é a coletividade) é sintomática da postura desiludida do cineasta frente aos ideais revolucionários. A opção de Back por um cinema que nega quaisquer teleologias condiz com o depoimento do próprio cineasta sobre o seu envolvimento frustrante com militantes favoráveis à luta armada e, segundo ele, repressores em relação à produção cultural (BACK, 1988).

À época do lançamento do filme, alguns críticos disseram que Ana decaiu à condição de figurante quando deixou de ser santa7. Em contrapartida, nota-se no tratamento pictórico dado à Ana na segunda parte da trama uma referência à figuração da liberdade, ainda que sob um enfoque um tanto fantasmagórico.

\section{A liberdade guia o povo?}

Se na primeira parte do filme os Pelados mantinham-se unidos, resistentes e pacíficos, após o fracasso mediúnico de Ana e o ataque sofrido durante a procissão, as coisas se complicam para o grupo. Daí para frente o filme passa a retratar apenas os confrontos bélicos entre os Pelados, que partem para a guerrilha, e seus opressores. Os camponeses liberam sua fúria: promovem incêndios, rasgam documentos e registros de propriedade das terras, atacam o trem que transporta autoridades e enfrentam os soldados embrenhados nas matas. Apesar do tema violento, essa fase do filme é tratada com extrema lentidão. Não há mais ênfase em conflitos pessoais, só nos combates. Nesse segundo bloco também se assiste à morte simbólica e solitária do Pai Velho, sinalizando a derrota efetiva da coesão pela fé. Mas essa cena da morte do líder religioso não é testemunhada por nenhum dos Pelados no contexto diegético. Ela se passa somente aos nossos olhos, como fragmento quase descolado da narrativa que continua se desagregando, esfacelando, até que o filme acaba sem um telos.

Essa fragmentação, bem como a descontinuidade na narração e a falta de densidade dramática foi motivo de queixas, diversas vezes, pelos críticos que interpretaram esse expediente como "ausência de profundidade", como "falta de um mergulho psicológico mais profundo nos personagens". De minha parte, tomo-a, aqui, como um dos traços definidores da 
poética cinematográfica de Back, uma vez que é característica presente também em outros filmes deste cineasta. Ele apresenta uma série de fragmentos de situações que precisam ser costuradas pelo próprio espectador, este que conferirá o sentido ao filme, conforme seu próprio repertório acerca dos assuntos ali tratados. Aos que buscam uma trama emocional na qual se agarrar, fica a sensação de vazio, pois Back constrói personagens-esquema mostrados apenas em sua superfície.

Em todo esse segundo bloco, a imagem de Ana torna-se mais espectral do que realista. Nos minutos finais do filme, os Pelados que sobrevivem ao massacre saem das terras que habitavam organizados em caravana, com Ana à frente. Vão derrotados os Pelados, sem santa e sem o seu líder espiritual. Mas Ana, desde que passou a figurar entre guerrilheiros, assumiu novo papel emblemático: o espectro da liberdade.

A cena em que os Pelados se preparam para invadir uma serraria é a primeira em que Ana acompanha a tropa dos guerrilheiros. Trata-se da única mulher nessas imagens, e é mais alegórica do que realista. Aparece empunhando uma bandeira, ora a cavalo, à frente dos homens, ora em pé, em meio às batalhas, mas sem nunca matar nem ser ferida. Compondo uma visão espectral em meio aos cenários bélicos, Ana agita a bandeira, invocando o monge e a morte dos inimigos: - Morra, em nome de São José Maria!

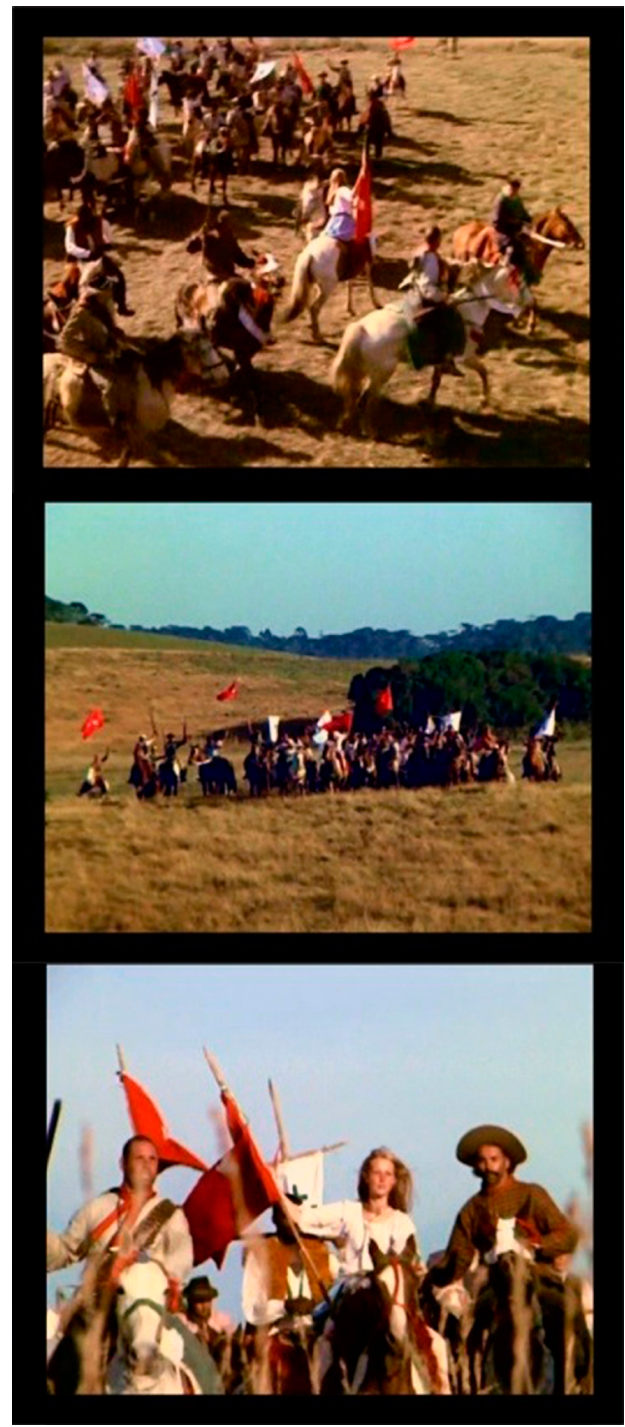

Figura 5: Os Pelados preparam-se para o combate. Ana empunha a bandeira e figura entre os guerrilheiros. $A$ Guerra dos Pelados (Sylvio Back, 1971).

Trata-se de uma composição em que a figura feminina à frente dos revolucionários, no campo de batalha, evoca com força a tela A liberdade guiando o povo, obra do pintor francês Eugène Delacroix inspirada pela Revolução de junho de 1830 e que glorifica a democracia (figura 6). Na tela se destacam os elementos em azul, branco e vermelho, e o conjunto compõe uma alegoria à França, à 
liberdade e ao povo francês.

Ana, no filme, não se transforma numa imitação dessa imagem, mas existe uma relação esquálida entre a liberdade representada por Delacroix e a nova função assumida por Ana na narrativa. Essa relação não se encontra numa equivalência do arranjo visual do quadro com alguma cena específica do filme. Ela reside, antes, na evocação dos elementos alegóricos: nas cores da bandeira francesa que se repetem no filme, e que no conjunto formam um signo forte e universalizado dos ideais revolucionários. Também reside na figura da mulher que agita a bandeira entre mortos, feridos e homens que lutam. Os que lutam olham para a imagem feminina como se olhassem para o seu ideal: um futuro em que se houvesse conquistado a liberdade ante as opressões e injustiças sociais. Um não-lugar.

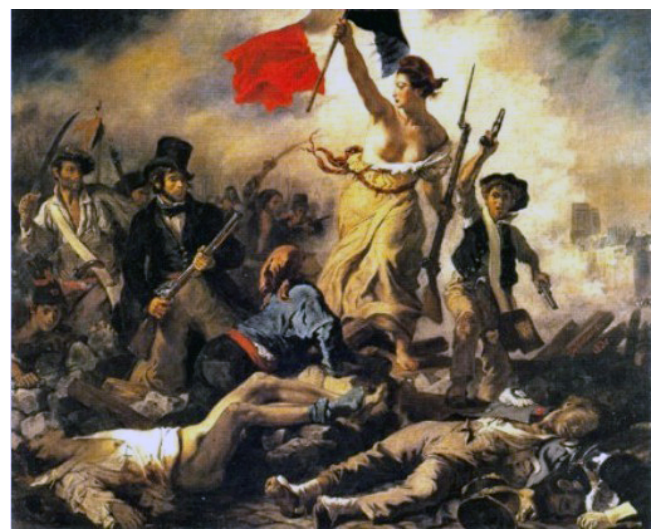

Figura 6: A liberdade guiando o povo. Eugène Delacroix, 1830.

A liberdade encarnada na figura pintada por Delacroix, além de levantar a bandeira, empunha na outra mão uma espingarda. $A$ certa altura do filme, Ana também aparece com uma arma nas mãos ao invés de bandeira. Isso ocorre quando os sobreviventes se organizam em retirada. Ana empunha uma espingarda e clama: - Viva a força dos Pelados! A essas alturas, seu brado é a conjuração de uma força já trucidada no embate contra forças bem maiores. Mesmo assim, sua imagem ainda é importante para manter viva a memória daquilo que o grupo havia sido no passado.

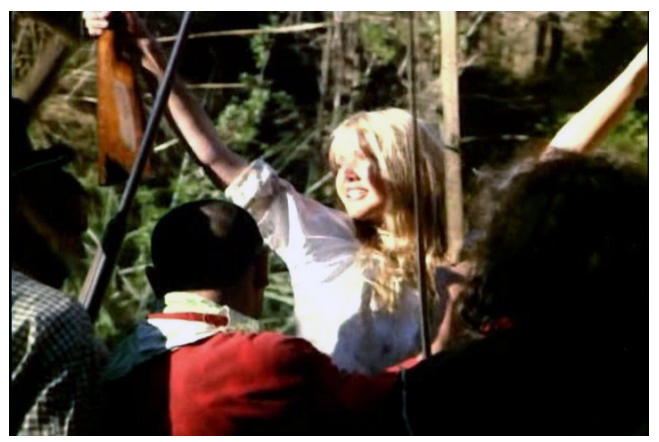

Figura 7: Ana (Dorothée-Marie Bouvier) empunha uma arma. A Guerra dos Pelados (Sylvio Back, 1971).

Ana passa, enfim, do papel de signo que integra um ritual místico capaz de promover a integração pelo consenso na fé, para signo da liberdade do povo a ser conquistada pela revolução. É a transmutação de um signo religioso para um signo político. Mas se a religião é de Deus e a política é do homem, Ana precisou sofrer um processo de "mundanização" para passar de um signo a outro: precisou mostrar-se como mulher, com vontade própria, desejos carnais e companheira do homem.

\section{Considerações finais ou a melancolia do alegorista}

Toda obra alegórica é também ambígua (GRAWUNDER, 1996: 110), permitindo mais de uma interpretação para os mesmos arranjos de elementos. Nesse sentido, outra forma de ver Ana como chave de leitura do filme, diante do seu contexto de produção, é deixar de lado a questão do signo religioso, e encarar as suas fases apenas como diferentes utopias sociais. Enquanto santa, Ana pode ser 
interpretada como uma utopia da sociedade civil, capaz de manter vivo o ideal comum do grupo que, unido, torna-se resistente aos poderes políticos e econômicos opressores. A fraqueza de Ana, sua entrega aos desejos mundanos, representa a própria fragilidade desta utopia que, arrefecida, coincide com a derrota dos Pelados na narrativa fílmica. Mas esta passagem não se dá de maneira tão simples: a ambiguidade do filme não permite ter certeza se Ana alimentava um desejo secreto de emancipação, pois, ao despir-se da condição de santa, passa a lutar pelos ideais do grupo ao lado dos homens. Alegoriza, em certa medida, uma nova utopia bastante alimentada no Brasil dos anos sessenta: o da conscientização social e do engajamento político.

Alguns anos após o lançamento do filme, o crítico Orlando Fassoni viu o valor de $A$ Guerra dos Pelados dentro do conjunto de filmes brasileiros afirmando que ele "serviu de ilustração às injustiças cometidas em nome da lei e da razão, e como exemplo de uma resistência que, se não alcançou seus fins, deixou sequelas para outros movimentos semelhantes onde os fracos tiveram de optar pelas armas para poderem sustentar seus legítimos direitos" (FASSONI, 1979). Contudo, a meu ver, há bem mais pessimismo do que motivação no enfoque dado ao tema por Sylvio Back. Ele ressalta tanto a ineficácia da fé que sublimava o instinto de revolta dos camponeses, quanto a inutilidade da resistência organizada em forma de guerrilha numa situação de embate entre forças tão desiguais, em que os poderes econômicos e políticos locais são aliados às forças do capitalismo internacional. Certamente seu olhar pessimista está fundamentado no evento histórico que desembocou no massacre da coletividade dos Pelados. Mas a narração funciona, por extensão, como alegoria do seu ceticismo quanto à tentativa de resistência ao modelo político e econômico em vigor no Brasil, naqueles anos de chumbo.

Enfim, a incredulidade que começa a aparecer na fala de Boca Rica já no início do filme, e que depois da transformação de Ana ultrapassa o âmbito religioso e se traduz no fracasso bélico é, ao mesmo tempo, um atestado da rejeição de Back às narrativas cinematográficas pautadas num modelo teleológico clássico, onde o final do filme deveria ser o coroamento de todo um processo. O fragmento da história da Guerra do Contestado que Sylvio Back escolhe para representar não mostra com clareza nem o início do conflito, e nem o final. Trata-se de uma fração de história. Ele privilegia exatamente o ponto de clivagem, onde se passa de uma imagem da força do coletivo unido pela fé e pela condição social, para uma imagem da derrota e da inutilidade de resistência. Sendo a ação de Ana que demarca esse ponto, pode-se dizer que a personagem alegoriza, em certa medida, o descrédito de Back quanto à eficácia das meta-narrativas, sejam elas históricas ou ficcionais.

A extrema lentidão que marca a segunda parte do filme, a "falta de densidade dramática" e ausência de profundidade psicológica dos personagens, produzem também um efeito de desânimo, de descrença, que pode ser entendido como expressão de melancolia, apontado por Benjamin como traço característico da "atividade do alegorista" (BURGER, 2012: 127).

Outro traço perceptível no filme que é próprio à alegoria, conforme apontado por Angus Fletcher é a descontinuidade (apud XAVIER, 2012: 446). De acordo com ele, o discurso alegórico apresenta brechas, lacunas, que tendem a colocar o receptor numa postura analítica.

Nesse sentido, pode-se afirmar 
que a dimensão alegórica das imagens representativas dessa transformação vivida por Ana no contexto diegético do filme não se restringe ao âmbito semântico do que é narrado, mas invade o dado formal. Ela define a clivagem numa narrativa marcada por momentos distintos e não orgânicos. A obra é alegórica também por não ter sido criada como um todo orgânico, e sim montada a partir de fragmentos ${ }^{8}$. A segunda parte de A Guerra dos Pelados, afinal, abre mão dos esquemas de encadeamento, tensão, clímax e desfecho tão recorrentes nas narrativas clássicas. É ausente qualquer elemento afirmativo, promissor ou redentor desde que Ana transmuta-se da condição de "santa" em "espectro da liberdade". Como efeito estético, resta uma sensação de incompletude e desconforto que emana da poética de Back, cineasta que construiu seu próprio espaço entre aqueles dispostos a posicionarem-se no mundo através de suas obras.

\section{Bibliografia:}

AMÂNCIO, Tunico. Artes e Manhas da Embrafilme. Niterói: EdUFF, 2000.

AZEREDO, Ely. A guerra dos pelados (II). Jornal do Brasil, Rio de Janeiro, 3 out. 1971.

BACK, Sylvio. Entrevista a Adélia Lopes e Dante Mendonça. O Estado do Paraná, Curitiba, 24 abr. 1988.

BELTING, Hans. Por uma antropologia da imagem. Concinnitas. UERJ, Rio de Janeiro, vol.1, n8, 2005.

BERNARDET, Jean-Claude. Qual é a história? In: Piranha no mar de rosas. São Paulo: Nobel, 1982.

BÜRGER, Peter. Teoria da vanguarda. São Paulo: Cosac Naify, 2012.

FASSONI, Orlando. Back na polêmica do filme engajado. Folha de São Paulo, 09 out. 1979.

GRAWUNDER, Maria Z. A palavra mascarada: sobre a alegoria, Santa Maria, Ed.UFSM, 1996.
KAMINSKI, Rosane. Poética da angústia: história e ficção no cinema de Sylvio Back (1960-70), Curitiba, 2008.

SANTAELLA, Lúcia e NÖTH, Winfried. Imagem: cognição, semiótica e mídia. São Paulo: lluminuras, 1998.

XAVIER, Ismail. O discurso cinematográfico: opacidade e transparência. São Paulo: Paz e Terra, 2005.

Alegorias do subdesenvolvimento. São Paulo: Cosac Naify, 2012.

\section{(Notas de fim)}

1 Trata-se do viés adotado em minha tese de doutorado, que envolve a análise dos três primeiros longas-metragens de ficção de Sylvio Back, produzidos entre 1968 e 1976. Sylvio Back nasceu em 1937 em Blumenau (SC). Mudou-se para Curitiba em 1957, onde atuou como crítico de cinema. Iniciou na direção de cinema em 1962, e desde então produziu mais de 40 filmes. Hoje mora no Rio de Janeiro. Sobre sua obra, ver: KAMINSKI, 2008.

2 Ao falar em montagem transparente, refiro-me à narrativa cinematográfica clássica. Segundo Ismail Xavier (2005: 32), "o que caracteriza a decupagem clássica é seu caráter de sistema cuidadosamente elaborado [...] para extrair o máximo rendimento dos efeitos da montagem e ao mesmo tempo torná-la invisível".

3 No seu livro Alegorias do subdesenvolvimento, Xavier analisa o caráter alegórico de um conjunto de filmes produzidos no Brasil em fins dos anos 1960, durante o regime militar brasileiro.

4 Vale lembrar que, já nos anos cinquenta, a temática histórica estava presente nas discussões sobre o caráter nacional e popular que o cinema brasileiro "deveria" adquirir. Em 1952, como nos conta Jean-Claude Bernardet (1982:58), o cineasta Nelson Pereira dos Santos, reconhecidamente de esquerda, afirmava que "a literatura, o folclore e a história deveriam ser as fontes do cinema brasileiro". Ele até mesmo sugeria temas, como Canudos e a Abolição da Escravatura, entre outros. Ou seja, esse estímulo que o governo Médici daria ao filme 
histórico não era um programa inédito, mas uma adaptação dos interesses nacionalistas da década de 1950 para os interesses de ufanismo característicos do regime militar.

5 BACK, Sylvio. Em entrevista concedida à autora em $1^{\circ} .09 .2003$.

$6 \mathrm{O}$ roteiro do filme foi elaborado a partir de pesquisa documental sobre o Contestado e da adaptação do romance Geração do Deserto escrito por Guido Wilmar Sassi e lançado em 1964.

7 É o caso, por exemplo, de Ely Azeredo (1971). 8 Para essa afirmação, estou tomando como referência as colocações de Peter Bürger (2012: 129-130) de que os aspectos produtivos da alegoria, segundo o conceito benjaminiano, coincidem com o que se pode entender por "montagem", e que a obra alegórica não é mais criada como um "todo orgânico", e sim "montada a partir de fragmentos". 